\title{
Young adults' personal views on child abuse
}

\section{Carolina Jernbro}

Public Health Science

Karlstad University

Email: carolina.jernbro@kau.se

\section{Ulla-Britt Eriksson}

Public Health Science

Karlstad University

Email: ulla-britt.eriksson@kau.se

\section{Staffan Janson}

Public Health Science

Karlstad University

Email: staffan.janson@kau.se

\begin{abstract}
This is a qualitative study based on reports from young adults, both exposed and not exposed to child abuse. The aim of the present study has been to analyse young adults' thoughts and feelings about child abuse. The data consisted of 358 responses to an open-ended question included in a national postal questionnaire study carried out by the Swedish Committee Against Child Abuse (Kommittén mot barnmisshandel). The analysis of data involved qualitative content analysis. Four main categories emerged: children's rights, consequences of child abuse, the role of the society, and causes of child abuse. The respondents who were abused as children wrote about the experience and the psychological long-term consequences of the abuse. The psychological abuse was particularly detrimental. The sexually abused expressed feelings of shame and guilt, in particular the young men. The nonabused respondents reported primarily on more general issues. They expressed children's right to a safe childhood and they strongly believed in stricter penalties for child abusers.
\end{abstract}

Keywords: child abuse, psychological abuse, physical abuse, sexual abuse, qualitative content analysis, children's rights 


\section{Introduction}

Child abuse is a public health problem which exists all over the world regardless of culture, ethnicity, and social class. Studies from countries around the world demonstrate that between 80 and 98 per cent of children experience corporal punishment in their homes, with a third or more suffering severe physical punishment (Waterston \& Mok, 2008). In 2002, approximately 150 million girls and 73 million boys under the age of 18 were victims of forced sexual intercourse or other forms of sexual violence (Pinheiro, 2006). Only 2.4 percent of the world's children are legally protected from corporal punishment in all settings, home, school, and penal systems (Pinheiro, 2006), even though all countries, except the United States and Somalia, have ratified the UN Convention on the Rights of the Child (CRC). The CRC contains 54 articles, of which article 19 is of greatest relevance to child abuse because it requires states to take a variety of measures - legislative, administrative, social, and educational - to protect children from all types of abuse (UNICEF, 2002).

Sweden was the first country in the world to prohibit all corporal punishment and any other humiliating treatment of children in 1979. Since the corporal punishment ban was introduced, there have been further changes in the legislation to protect children from abuse. In 1982, the legislation was amended so that assaults against children occurring in private places, for instance, in the home, could be publicly prosecuted. Corporal punishment was no longer a private matter.

A number of Swedish studies have shown that the use of corporal punishment of children and positive attitudes towards corporal punishment have decreased significantly since the ban on corporal punishment was introduced (Janson, Svensson, \& Långberg, 2010). In the year 2000, only eight per cent of the parents reported having punished their children corporally in the past year, compared to 51 per cent in 1980 (SOU, 2001a).

The definition of child abuse proposed by The Swedish Committee Against Child Abuse (Kommittén mot barnmisshandel) reads as follows:

Child abuse is when an adult subjects a child to physical or psychological violence, sexual assault, humiliating treatment or fails to meet the child's basic needs (SOU 2001b, p.120).

The definition above, which is based on the definition of 1999 from the World Health Organization (WHO, 2002), adopts the perspective of the child and does not incorporate cultural standpoints. Further, it distinguishes neither between intentional and unintentional acts nor between active and passive neglect (SOU 2001b).

The definition of the different types of abuse is presented in table 1 below. 


\begin{tabular}{|c|c|c|}
\hline Type of Abuse & Definition & Examples \\
\hline $\begin{array}{l}\text { Physical abuse, } \\
\text { including } \\
\text { physical neglect }\end{array}$ & $\begin{array}{l}\text { Physical abuse is when an adult causes the child } \\
\text { physical injury, illness, pain, or puts the child in a } \\
\text { position of powerlessness or similar state. Physical } \\
\text { neglect is when an adult hurts or jeopardizes a child's } \\
\text { physical health or development by failing to guarantee } \\
\text { the child an acceptable standard of physical care. }\end{array}$ & $\begin{array}{l}\text { Hitting, kicking, scratching, } \\
\text { pinching, biting, poisoning, } \\
\text { burning, scalding, trying to } \\
\text { drown or suffocate the child. } \\
\text { Neglect in the form of hygiene, } \\
\text { nutrition, clothes, rest, shelter, } \\
\text { etc. }\end{array}$ \\
\hline $\begin{array}{l}\text { Psychological } \\
\text { abuse, } \\
\text { including } \\
\text { psychological } \\
\text { neglect }\end{array}$ & $\begin{array}{l}\text { Psychological abuse is when an adult systematically } \\
\text { or during a longer period of time, exposes a child to } \\
\text { discrimination, destructive treatment or intentional } \\
\text { emotional suffering. In serious cases, one occasion is } \\
\text { enough to be classified as abuse. Witnessing } \\
\text { violence between parents is also psychological } \\
\text { abuse. Psychological neglect is when an adult hurts } \\
\text { or jeopardizes a child's physical health or } \\
\text { development by failing to meet a child's basic need } \\
\text { for attention, guidance, and so forth. Psychological } \\
\text { abuse is present in all forms of physical and sexual } \\
\text { child abuse. }\end{array}$ & $\begin{array}{l}\text { Criticizing, ridiculing, } \\
\text { dismissing, and isolating the } \\
\text { child from social contacts. } \\
\text { Neglect in form of unavailability, } \\
\text { failing to provide the child with } \\
\text { experiences and to teach the } \\
\text { child right from wrong. }\end{array}$ \\
\hline Sexual abuse & $\begin{array}{l}\text { Sexual child abuse involves all forms of sexual acts } \\
\text { that are forced upon a child by an adult. }\end{array}$ & $\begin{array}{l}\text { Non-contact sexual acts; } \\
\text { exhibitionism, voyeurism, } \\
\text { sexual indications, comments, } \\
\text { and suggestions, as well as } \\
\text { exposure to pornographic } \\
\text { material. Sexual touching and } \\
\text { sexual penetration. }\end{array}$ \\
\hline
\end{tabular}

Table 1. Definitions of the different types of abuse (SOU 2001b)

The burden and consequences of child abuse in the western part of the world have recently been analysed in a comprehensive review based on 172 scientific articles, where one of the authors of the current article took part. One of the key findings was that the experience of abuse during one's childhood increases the risk for long-term health consequences, such as mental health problems, drug and alcohol problems, risky sexual behaviour, obesity, and criminal behaviour (Gilbert et al. 2008). Abused children are at increased risk for depression during adolescence and adulthood. Between 25 and 30 per cent of abused children meet the DSM (Diagnostic and Statistical Manual of Mental Disorders) criteria for major depression by their late twenties. Depression is associated with all types of abuse: psychological, physical, and sexual (Gilbert et al., 2008). A study by Straus (1998) has shown that the more physical abuse children experienced, the more depressive symptoms they showed in their youth and the more often they had thoughts about committing suicide. Further, child abuse has a negative impact on the ability to establish and maintain healthy intimate relationships in adulthood (Colman \& Widom, 2004).

Few qualitative studies have been conducted examining children's and adolescents' self-described feelings and experiences of child abuse. There have been, however, some studies of children and adolescents' experiences of growing up witnessing violence between their parents (Mullender et al., 2002; Weinehall, 1997) and of being victimized by sexual abuse (Jensen et al., 2005). The qualitative approach is important because it allows the study participants to speak in their own voices. In this way, the realities that often are missed in quantitative methods can be revealed (O'Day \& Killeen, 2002). Children's and young people's participation in research is also of great importance in order to obtain the child's perspective. Their testimonies and descriptions are needed in order to develop appropriate preventative strategies against child abuse (Eriksson et al., 2008). 


\section{Aim of the study}

The main aim of the present study was to analyse young adults' thoughts and feelings about child abuse based on the following three research questions:

Did the respondents with experience of child abuse express different thoughts and feelings compared to the respondents without experience of child abuse? Did the thoughts and experiences differ depending on what type of abuse the persons had been exposed to? Were there any gender differences?

\section{Method}

\section{Sample and data collection}

In the year 2000, the Swedish Committee Against Child Abuse carried out a national study containing three parallel surveys to determine the frequency and extent of child abuse at the time. The surveys consisted of one interview study with parents, one classroom questionnaire directed to children ages ten to 12 , and a third survey, of which this present study is a component. The third survey was a postal questionnaire study regarding upbringing and was directed to young adults. The questionnaire was constructed from previous studies conducted by the Centre for Studies of Children at Risk at McMaster University in Ontario, Canada, and included questions about psychological, physical, and sexual abuse (MacMillan et al., 1997). The Swedish survey was addressed to 2500 randomly chosen twenty-year-olds throughout the country. There were 1576 (63 per cent) of these young adults who completed the questionnaire, a satisfying response rate taking into account that young adults often are on the move. The quantitative results of the survey have been published earlier (SOU 2001a).

At the end of the questionnaire there was an open-ended, free-text question: Feel free to express your thoughts and opinions regarding child abuse in your own words. There were 358 young adults who responded to this item. Their texts constitute the material analysed in the present study.

\section{Analysis}

Qualitative content analysis was used when analysing this free-text data. Content analysis is an empirically based method used to draw reliable and valid conclusions from a text (Krippendorff, 2004). Qualitative content analysis offers great opportunities for interpretation. It can focus on the manifest content, that is, describing the visible and obvious elements of the text. The method can also focus on the latent content, which is the underlying, deeper meaning of the text. Both manifest and latent content involve interpretation, but vary in depth and level of abstraction (Graneheim \& Lundman, 2004).

The analytical process started with an overview of the textual material, followed by several thorough readings. Next, the meaning units, that is, the phrases relevant to the aim of the study, were chosen from the texts. These units were condensed in order to shorten the text without changing the original meaning. Thereafter, all condensed meaning units were coded and grouped into subcategories. Following this step, we then merged the subcategories into four main categories. This process is presented under each category in the results section (figures $1-4$ ). The interpretation has focused mainly on the manifest content, but with elements of the latent content of the texts. To ensure credibility, three researchers have been involved in the analytical process. Quotations have also been included in the results to illustrate and 
verify the interpretation. In addition, a quantitative analysis was done in order to see how representative the subsample was in relation to the main sample.

\section{Ethical considerations}

Child abuse is a sensitive issue, and there is a risk that a study designed to examine the matter can arouse unpleasant memories and feelings in the respondents. On the other hand, a positive aspect of this study is that the participants have the opportunity to express their views and experiences of the matter confidentially. The survey including the open-ended question was approved by the Statistics Sweden's ethics committee in the year 2000. Participants were given the opportunity to refrain from answering the questionnaire, or any item in it, including the open question. The material did not contain any information that can identify the participants in the study.

\section{Quantitative results}

There were 1576 twenty-year-olds who participated in this national study of child abuse (the main survey). Of the participants, 576 young persons (36.5 per cent) reported that they had been physically punished or sexually abused during childhood. The most common forms of punishment were slapping and the pulling of the child's hair. The questionnaire also included six questions related to psychological abuse: if they had been insulted by an adult, locked out of home, threatened with physical punishment, or if an adult had acted neglectfully. Twenty-two per cent responded that they had been threatened with physical punishment and nearly 15 per cent answered that adults had acted neglectfully. The results also showed a relationship between poor family economy and reported abuse (SOU 2001a).

There were 358 of the 1576 participants who answered the open-ended question at the end of the questionnaire. Of those who answered the last item, 66 (50 women and 16 men) had been victims of child abuse of some kind. The distribution of the young adults in the subsample who experienced different types of child abuse is presented in Table 2. The classification of the types of abuse is based on the definitions in Table 1.

\begin{tabular}{|l|c|c|c|}
\hline Type of Abuse & Men & Women & Total \\
\hline Psychological & 1 & 3 & 4 \\
\hline Physical \& Psychological & 8 & 21 & 29 \\
\hline Sexual \& Psychological & 2 & 9 & 11 \\
\hline $\begin{array}{l}\text { Sexual, Psychological \& } \\
\text { Physical }\end{array}$ & 5 & 17 & 22 \\
\hline Total & 16 & 50 & 66 \\
\hline
\end{tabular}

Table 2. The distribution of the young adults who have been victims of child abuse according to type of abuse and gender. Note that those who had been physically and sexually abused also were subjected to psychological abuse. 
Of those who had answered the open-ended question, 61 per cent were females, while in the main sample the gender distribution of respondents was 54 per cent females and 46 per cent men. Compared to the main sample, there were fewer abused men who answered the open-ended question. Of the 268 young men who reported being abused in the main sample, only 16 answered the open-ended question (six per cent of male respondents reporting abuse). Of the 308 women who reported experience of child abuse in main survey, 50 shared their views and experiences by answering the open question (16.2 per cent of female respondents reporting abuse). It was nonabused participants who most frequently gave their views, feelings, and attitudes towards child abuse. Of the 453 young men who in the questionnaire reported having no experience of abuse, 122 shared their views in the openended question (26.9 per cent of male respondents who did not report abuse). Of the 545 young women who in the main survey reported not having been victims of any child abuse, 170 answered the open-ended question (31.2 per cent of female respondents who did not report abuse).

\section{Qualitative results}

The analysis of free-text answers resulted in four main categories: children's rights, consequences of child abuse, the important role of society, and causes of child abuse. The process of the analysis is presented under each main category.

\section{Children's rights}

The emergence of the category 'children's rights' is described in Figure 1.

\section{Code}

- Child abuse is never justifiable

- Children should never be abused

in any way

- Children need a safe upbringing

- Children need love and care

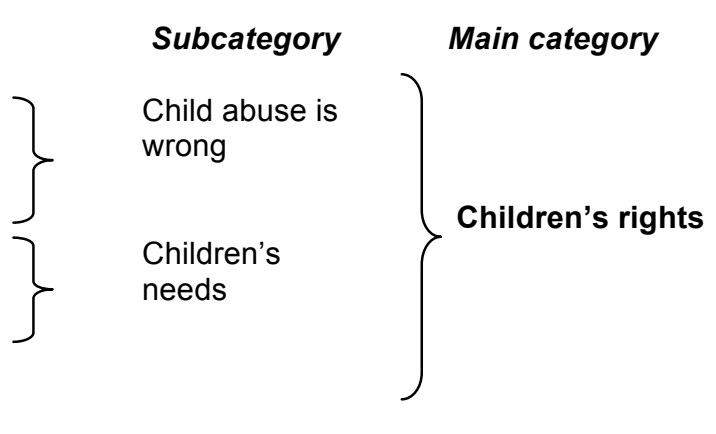

Figure 1. The emergence of the main category "children's rights"

The majority of the respondents expressed that all child abuse is wrong. They argued that children have a right to a childhood without abuse. This was expressed very strongly, regardless if they were victims of child abuse or not. They also described what children need in order to develop and thrive, such as love and safety. A woman who was not abused as a child stated:

All types of abuse are disgusting! Using violence in any way (physically, psychologically) against children can never be justified. We need to look at children as individuals with their own feelings and their own rights. Children are human beings and adults must help them to become 'good' adults. That will be difficult if corporal punishment is used in the upbringing. Protect the child instead and we will get a safer society. All children have a right to be loved and cared for. No one has the right to violate someone else! 
Some respondents who grew up in non-abusive families reflected on their childhoods. They expressed gratitude for 'being lucky' to have had a good upbringing, while they argued that good rearing should be a matter of course for all children.

\section{Consequences of child abuse}

The emergence of the category 'consequences of child abuse' is described in Figure 2 below.

\section{Code}

- Never forget the abuse

- Repression of hurtful memories

- Feeling blue and depressed

- Feelings of despair

- Feeling insecure

- Abuse creates hate

- Abuse lowers self-esteem

- Abuse transfers from one generation to the next

- Abused children will think it is acceptable to insult and beat others

- Harder to prove mental abuse

- Mental abuse leaves deeper wounds than physical abuse

- Witnessing family abuse is more devastating than self being abused

- Blame themselves for the sexual abuse

- Difficult to disclose sexual abuse

- Not taken seriously by authorities

- Difficult to have normal sexual relations because of memories

- Visions of children in sexual context
Subcategory

Main category

Painful

memories<smiles>CCCCCC</smiles>

\}

Depression

Insecurity, low self-esteem hatred

The cycle of violence<smiles>CCCCCC</smiles>

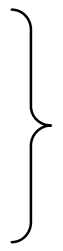

Consequences of psychological abuse

Consequences of sexual abuse
Consequences of child abuse

Figure 2. The emergence of the main category 'consequences of child abuse'

Many of those who had been victims of child abuse wrote about their own experiences of abuse and its consequences, with the emphasis on psychological consequences. It appears clear that many respondents were experience lasting hurt, no matter what type of abuse they had been exposed to. Many respondents expressed painful memories about the abuse. Usually, 
they reported that they had tried to repress the memories, but they often recurred in adolescence and adulthood and haunted them throughout their lives. The memories were so deep that it was difficult to process them, even with help from professionals. A woman who had been a victim of psychological and physical abuse as a child expressed this experience as follows:

To abuse a child is the most vicious thing an adult can do. It leaves a wounded soul that takes many years to heal. Sometimes it does not heal, which will give you psychological damage that you have to live with for the rest of your life! Sure, you can try to process the memories of abuse with therapy and anti-depressants, but if you have been abused both psychologically and physically, you do not forget the words or blows no matter how much therapy you get.

Some of the respondents who had been victims of child abuse wrote that they suffered from depression. A man who was physically and psychologically abused wrote the following:

My dad was brought up in an East European way, which means beatings and punishments. This made him hit me as well. I feel awful about this, and I think about it quite often. I am suffering from depression. Do not know what to do with myself.

Some of the respondents who were abused when growing up expressed insecurity and low self-esteem, which they attributed to abuse. They wrote that children easily adapt to situations and therefore accept the abuse. Most often they also believed that they deserved to be maltreated. However, a couple of respondents wrote that they had feelings of hatred towards the perpetrators as a result of abuse.

The cycle of violence is a consequence of child abuse that was particularly noted by non-abused respondents. These respondents expressed that parents shape their children's characters and argued that children who are exposed to humiliation and corporal punishment when growing up will think that it is acceptable to insult and beat others. They also expressed the view that violence will be transmitted from one generation to the next.

Consequences suffered by respondents who experienced abuse differed depending on what type of abuse the respondents had been exposed to during childhood. Many of the respondents argued strongly that psychological abuse is as detrimental as physical abuse. Some of the respondents claimed that the psychological abuse was worse since it was easier to overcome physical blows than humiliation. The consequences of psychological abuse were not visible in the same way as physical abuse and was therefore harder to prove (to one's self or concerned others, or both). A young man described the psychological abuse by his stepfather as follows:

What happened during those years is so damned hard to describe, and that in itself has been a major problem. Never been able to prove what happened. I wished many times that he could beat me instead so that I would be able to demonstrate to my mother how he really was. What happened (in broad terms) was that it started gradually and then it intensified. Exclusion, insults, mental humiliation, threats, staring, blaming, oppression, ridicule. Everything happened behind the back of others. I was the only one who knew.

Being witness to violence within the family was often described as devastating as being a victim oneself. One woman stated that witnessing violence against her brother had more damaging impact than the abuse directed at her. 
Another woman wrote that she struggled with depression because of the abuse she witnessed between her parents.

Those who had been sexually abused wrote about painful memories and feelings of shame and guilt. Some blamed themselves for the abuse, which made it difficult to disclose this abuse to others. This was especially true for the male respondents. A man who had been sexually abused as a child wrote about the shame:

The reason I never told anyone about the sexual abuse is because I was ashamed. I was convinced that I did something wrong. It took me many years to realize that this was not the case. Now it's too late. My secret.

The sexually abused respondents who had the courage to report incidents to the authorities said they had felt violated during the interrogations.

I was abused as a child by a paedophile in the neighbourhood. The police said it was not worthwhile to report. So we never did. When I was fifteen, I was sexually abused by an older guy and I decided to report it. In a way, I regret that now. The interrogations of prosecutors and police were extremely insulting. They humiliated me and were very insensitive. Have met others in my situation, and heard the same thing from them. The chance of getting the offender convicted is extremely small.

Some respondents who had been sexually abused as children described the difficulties in having normal sexual relations with partners because of the recurring painful memories. A couple of respondents also wrote that they had thoughts of children in a sexual context and were afraid of becoming perpetrators themselves.

\section{The important role of society}

The emergence of the category 'the important role of society' is described in Figure 3 on the following page.

Many respondents, both in the abused and non-abused groups, thought that the social environment is of great importance for giving children support when needed. Respondents felt that schools and authorities play a critical role in addressing abuse, but that legal systems are also important so that justice is done for victims of child abuse. The combined group also expressed the need for an increased openness about child abuse in society. Many of those who had been victims of some form of abuse reported that they had no adult to talk to about their experiences during their childhoods. The need to talk about the abuse was obvious in many responses. One woman wrote, 'I want to discuss further', another person wanted to be phoned and left a phone number. Some respondents thought that the survey instrument did not include enough space for their free-text answers. 


\section{Code}

- Penalties for perpetrators of child abuse are not strict enough

- Psychological abuse should be as punishable as physical abuse

- Child molesters deserve the death penalty or castration

- Society should be more open

- It is important to take abused children seriously

- It is important for everyone to be aware and to notify the social authorities if necessary

- It is hard to know what to do if a child is abused

- School staff can detect abuse

- Can get information about children's rights in school

- Social authorities need to adopt a children's perspective

- The health-care system lacks resources

- It should be easier for victims and perpetrators to receive the help they need
Subcategory

Main category

\}

Need for stricter penalties

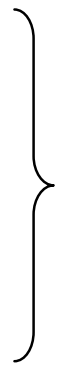

Need for greater awareness in the community

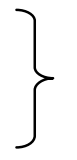

The importance of the school setting

The approach of the authorities

Need for strengthened resources in health care
The important role of society

Figure 3. The emergence of the main category 'the important role of society'

The need for stricter penalties for offenders was expressed very strongly by the combined groups of respondents, but to a greater extent and in a more intense way among those who had not been subjected to child abuse. A woman who had not been exposed to abuse when growing up stated:

I believe that those who assault children do not get the penalty they deserve. Children cannot for the most part protect themselves and if there is hardly any punishment of the offenders, the world becomes an insecure place for them to live in. A couple of months in prison for a destroyed life and a ruined future. The perpetrators are pampered. I think a proper strengthening of the penalties and a legal review would be appropriate. I have no confidence in the legal system.

The respondents who had been psychologically abused thought that this type of abuse needs to be considered as serious as physical abuse and should be as punishable. When the respondents wrote about the penalties for those who have abused children sexually, very strong feelings were expressed. Many suggested the death penalty or castration.

Many of the respondents thought there is a need for greater awareness regarding the problem of child abuse in the general population. The respondents expressed that there should be an openness in society that could 
facilitate the disclosure of abuse without children feeling stigmatized. It is also important for adults to pay attention to abused children and to take disclosures seriously so that the children can get the appropriate help in time. Some respondents wrote about the importance of notifying the social authorities when child abuse is suspected. They argued that everyone who suspects child abuse is obligated to intervene. On the other hand, some respondents who were not exposed to child abuse wrote about the difficulty to detect child abuse and about not knowing what to do when they suspect that a child is abused. A couple of respondents also mentioned the importance of organizations such as Children's Rights In Society (Barnens Rätt I Samhället, BRIS), where children can anonymously talk on the telephone to adults about issues affecting them.

Several respondents argued that the school setting is central in addressing child abuse. The respondents wrote that the school can give children information about their rights. The school is also a setting where child abuse can be detected and therefore it is crucial that teachers and other staff are responsive to the children. The respondents also stressed the importance of school resources, such as counsellors and school nurses. A woman who was psychologically and physically abused as a child wrote:

\footnotetext{
I turned 'into myself' when I was bullied / beaten at home. This led to depression which the school nurse and school counsellor discovered by chance and resulted in therapy. Guess if I get upset when I see how these services (school nurse, school counsellor) are removed from schools. I would probably not be alive today if they would not have been there for me!
}

Some respondents wrote about the importance of appropriate responses from authorities. Respondents stated that the social authorities need to take the children's perspective into account when they approach an abused child. When a child discloses and asks for help from the authorities concerned, the child should be listened to and taken seriously. Some respondents who had been abused wrote about their unpleasant experiences with the social authorities. One woman who was abused as a child wrote:

\begin{abstract}
Incest and corporal punishment are absolutely illegal and adults need to be aware of this. A social worker was sent home to my stepmother when I was five-six years old and my stepmother admitted that she hit me. The social worker made her promise never to do it again and that was it. Obviously everything got worse after that, because I was accused of bringing the social worker home. This is unacceptable! Nobody should have to be afraid of being beaten in their own home.
\end{abstract}

A number of respondents expressed the need for strengthened resources in health care. They believed that medical and psychiatric services should be improved so that both victims and perpetrators can get the help they need within a reasonable time.

\title{
Causes of child abuse
}

The emergence of the category 'causes of child abuse' is described in Figure 4 on the next page. 


\section{Code}

- A lack of parenting skills can be

a contributing factor to child abuse

- Abusers have psychological problems

- Abusers have been abused

themselves during childhood

- Corporal punishment is needed occasionally to teach right from wrong

- Corporal punishment is not the

same thing as abuse

- Immigration; many cultures and

religions allow corporal punishment;

they do not know better

- The gender inequality is a

contributing factor to child abuse

\section{Subcategory \\ Subcategory}

Main category

\}

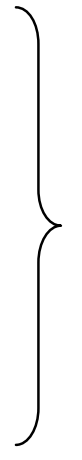

Causes attributable

to caretaker

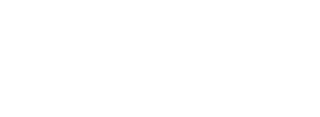

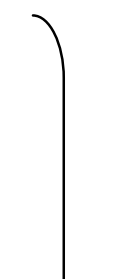

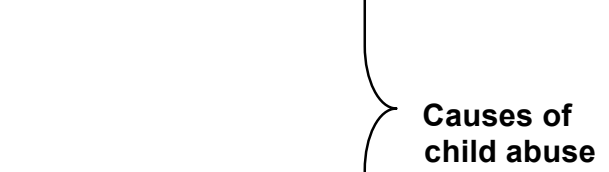

Causes attributable to society

Figure 4. The emergence of the main category 'causes of child abuse'

Respondents frequently stated that there are no excuses for child abuse. However, many respondents attributed causes of child abuse. Some respondents argued that causes of abuse are attributable to the caretaker, such as a lack of parenting skills. A number of respondents wrote that those who abuse children have psychological problems - a common explanation was that abusers are 'sick'. They also wrote that the perpetrators are likely to have had an insecure childhood and that they probably had been exposed to abuse themselves. A couple of respondents wrote that some parents abuse their children because they like to exercise power over another human being.

Some respondents wrote that the causes of child abuse are attributable to social factors. Some brought up the rise of immigration to Sweden, which has led to a multicultural society, as an explanation for some child-abuse cases, because many cultures and religions allow corporal punishment in the upbringing of children. A couple of respondents had a greater understanding that parents of foreign origin and culture spank their children. On the other hand, some respondents thought that religions that advocate corporal punishment should be prohibited in Sweden.

One respondent felt that gender inequality is a contributing factor to child abuse. She wrote that women are less likely to use physical force against their children, compared to men. She argued that if women were to become more influential in the society, their more gentle ways would reflect upon society.

No respondent felt that children benefited from regular physical punishment, but a few respondents, even those who had not themselves been abused, wrote that they think that corporal punishment is necessary at certain times when the child has misbehaved. Corporal punishment should only be used occasionally to teach the child right from wrong, they wrote. The respondents who were positive to corporal punishment distinguished between corporal punishment and abuse. 


\section{Discussion}

This study is based on a nationally representative sample of young people with or without experience of abuse expressing their views regarding child abuse. To our knowledge, no such study has been reported before. Previous studies are entirely based on reports from victims.

The major difference between the responses from the non-abused and the abused respondent groups was that the victims of child abuse often wrote about their own personal experiences of the abuse and its consequences, while the non-abused group merely offered their opinions on public institutions and children's rights. Since the non-abused have no personal experience to refer to, they reported primarily on more general issues, or on the basis of reports from abused peers. The non-abused answered the open-ended question to a higher degree, while abused men shared their thoughts and experiences the least.

One finding of the present study is that many of the victims of child abuse, regardless of the type of abuse, expressed that they had been harmed psychologically from the abuse. The psychological consequences differed to some extent depending on the type of abuse the person had experienced. Those who were victims of sexual abuse often described feelings of shame and guilt, especially the young men. This is in line with other findings (Dorais, 2002; Feiring, Taska \& Lewis, 1996; Finkelhor \& Brown, 1985). A few respondents also expressed the fear of becoming perpetrators themselves. There are studies that suggest that there is an increased risk that victims of child sexual abuse may become perpetrators later in life. Although far from all the perpetrators have been victims of sexual abuse, this relationship between childhood victim and adult perpetrator is still two to three times higher in perpetrator groups than in the general population (Svedin \& Banck, 2002). There also seems to be a greater need for respondents who were sexually abused to share their experiences since the victims of sexual abuse in our study represented half of the abused respondents in the subsample. It is possible that it was the first time for many of the sexually abused respondents to share their experiences of the abuse. This supposition can be supported by the fact that about half of the sexually abused respondents reported in the main survey that they had no adult they could trust enough to disclose their experiences of abuse during childhood and adolescence (SOU, 2001a).

Our study has found that psychological abuse can be just as destructive as physical abuse. Some of the respondents who reported having experienced physical and psychological abuse claimed that the psychological abuse was worse and that more attention needs to be paid to this type of abuse. Psychological abuse, including neglect, is a subject that has not received much scientific and public attention in comparison to other types of abuse (Gilbert et al., 2008). Research shows that psychological maltreatment in childhood is related to a number of emotional problems later in life, such as anxiety, depression, and somatic complaints (Allen, 2008; Higgins \& McCabe 2000; Spertus et al., 2003). All children who are victims of physical and sexual abuse are also psychologically abused because abuse always violates the child's integrity. Physical and sexual abuse is also often coupled with psychological threats and insults (SOU 2001b). Such violation can hurt as much as the physical pain. This is in line with Eisenberger, Lieberman, and Williams' (2003) finding that social pain (e.g., exclusion, rejection) shows the same pattern in the brain as physical pain.

Opinions expressed by non-abused respondents highlighted the great importance of institutions such as schools, social services, legislation, child rights organizations, and health care to prevent child abuse and to pursue measures for reducing the consequences of the abuse. These respondents 
strongly and frequently criticized the penal system, which they expressed as too weak to result in stopping abuse. By comparison, opinions on the broader subject of children's rights and penalties were not expressed in such a strong fashion by respondents who had been victims of child abuse. However, some of them wrote about their own experience of public institutions. A couple of respondents who had been in contact with the Social Services and Police Department wrote about their unsatisfactory experiences. They expressed that they have not received the support they needed. A study by Lindell and Svedin (2004) has shown that social services in Sweden has experienced difficulties in enacting and enforcing adequate measures to end child abuse and to prevent the continuance of the abuse in many cases they pursued. Many abused children did not receive the health care and treatment they needed in order to recover, according to this study.

One limitation of the present study relates to problems concerning adult recall. When adults are trying to remember and describe negative experiences during their childhood, it is common to forget or distort the memories. Forgetfulness and dissociation are especially common among those who have experienced serious abuse (Femina, Yeager \& Lewis, 1990). Consequently, there is a possibility that the most serious cases of child abuse are not represented in this present study.

Another limitation is that the material currently analysed was obtained in the year 2000. It is possible that the results could be different if the same study were done with the twenty-year-olds of today, in 2010. Child abuse is an issue which has been discussed more frequently the past ten years, and it is possible that young people have been informed about children's rights in school and other public institutions to a greater extent over the past ten years. It is possible that, fewer people today believe that spanking is acceptable. The increasing number of police reports of child abuse indicates a reduced tolerance for abuse (National Council for Crime Prevention, 2000). However, the experiences and consequences that the abused have described would probably be the same today.

This present study has indicated that many respondents felt a need to express their thoughts and feelings about child abuse. Many of them wrote long and detailed texts and some commented on the great importance of studies concerning the matter. It may be easier for respondents to express feelings, thoughts, and experiences in writing because of the feeling of anonymity provided by confidential surveys. However, using the answers from an openended question is a somewhat limited way to collect data. It is difficult to derive the deeper meaning merely from written text, since there is no opportunity to ask follow-up questions and to interact with participants. Indepth interviews with victims of all types of child abuse would therefore complement this study. We note that the issues relating to the psychological abuse of children need to be explored further, both quantitatively and qualitatively, in order to develop more fully our knowledge on the long-term impact of this type of abuse.

\section{References}

Allen, B. (2008). An analysis of the impact of diverse forms of childhood psychological maltreatment on emotional adjustment in early adulthood. Child Maltreatment, 13(3), 307-312. 
Colman, R. A., \& Widom, C. S. (2004). Childhood abuse and neglect and adult intimate relationships: A prospective study. Child Abuse \& Neglect, 28(11), 1133-1151.

Dorais, M. (2002). Don't tell: The sexual abuse of boys. Montreal: McGill-Queens University Press.

Eisenberger, N. I., Lieberman, M. D. \& Williams, K. D. (2003). Does Rejection hurt? An fMRI study of social exclusion. Science, 302(5643), 290-292.

Eriksson, M., Cater, Å.K., Dahlkild-Öhman, G., \& Näsman E. (2008). Barns röster om våld: att tolka och förstå [Children's voices about violence: to interpret and understand] (1st edition.). Malmö: Gleerups.

Femina, D. D., Yeager, C. A., \& Lewis, D. O. (1990). Child abuse: Adolescent records vs. adult recall. Child Abuse \& Neglect, 14(2), 227-231.

Feiring, C., Taska, L., \& Lewis, M. (1996). A process model for understanding adaptation to sexual abuse: The role of shame in defining stigmatization. Child Abuse \& Neglect, 20(8), 767-782.

Finkelhor, D., \& Browne, A. (1985). The traumatic impact of child sexual abuse: A conceptualization. American Journal of Orthopsychiatry, 55(4), 530-541.

Gilbert, R., Widom, C. S., Browne, K., Fergusson, D., Webb, E., \& Janson, S. (2009). Burden and consequences of child maltreatment in high-income countries. The Lancet, 373(9657), 68-81.

Graneheim, U. H. \& Lundman, B. (2004). Qualitative content analysis in nursing research: concepts, procedures and measures to achieve trustworthiness. Nurse Education Today, 24(2), 105-112.

Higgins, D. J., \& McCabe, M. P. (2000). Relationships between different types of maltreatment during childhood and adjustment in adulthood. Child Maltreatment, 5(3), 261-272.

Janson S., Svensson B., \& Långberg B. (2010). Sweden: A 30-year ban on physical punishment of children. In Durrant J \& Smith A. (Eds), Global pathways to abolishing physical punishment: realizing children's rights. London: Routledge publications (in press).

Jensen, T. K., Gulbrandsen, W., Mossige, S., Reichelt, S., \& Tjersland, O. A. (2005). Reporting possible sexual abuse: A qualitative study on children's perspectives and the context for disclosure. Child Abuse \& Neglect, 29(12), 1395-1413.

Krippendorff, K. (2004). Content analysis: An introduction to its methodology. Thousand Oaks, CA: Sage.

Lindell, C. \& Svedin, CG. (2004). Social Services provided for physically abused children in Sweden: Background factors and interventions. International Journal of Social Welfare, 13(4), 340-349.

MacMillan, H. L., Fleming, J. E., Trocmé, N., Boyle, M. H., Wong, M., Racine, Y. A., Beardslee, W. R., \& Offord, D. R. (1997). Prevalence of child physical and sexual abuse in the community: Results from the Ontario health supplement. Jama, 278(2), 131-135.

Mullender, A., Hague, G., Imam, U., Kelly, L., Malos, E. \& Regan, L. (2002). Children's perspectives on Domestic violence. London: Sage Publications.

National Council for Crime Prevention. (2000). Barnmisshandel. En kartläggning av polisanmäld misshandel av små barn [Child abuse: A study of reported child abuse]. Brårapport 2000:15.

O'Day, B., \& Killeen, M. (2002). Research on the lives of persons with disabilities: The emerging importance of qualitative research methodologies. Journal of Disability Policy Studies, 13(1), 9. 
Pinheiro, P.S. (2006). World report on Violence against Children. Geneva: United Nations.

SOU (2001a). Barn och misshandel. En rapport om kroppslig bestraffning och annan misshandel $i$ Sverige vid slutet av1900-talet [Children and abuse: A report about corporal punishment and other forms of abuse in Sweden at the end of the 20th century]. SOU 2001:18.Stockholm, Fritzes.

SOU (2001b). Barnmisshandel: att förebygga och åtgärda [Child abuse: prevention and protection]. SOU 2001:72. Stockholm: Fritzes.

Spertus, I. L., Yehuda, R., Wong, C. M., Halligan, S., \& Seremetis, S. V. (2003). Childhood emotional abuse and neglect as predictors of psychological and physical symptoms in women presenting to a primary care practice. Child Abuse \& Neglect, 27(11), 1247-1258.

Straus, M. A. (1998). Corporal Punishment of Children and Adult depression and Suicidal Ideation. New York: Cambridge University Press.

Svedin, C.G. \& Banck, L. (2002). Sexuella övergrepp mot flickor och pojkar [Sexual abuse of girls and boys]. Lund: Studentlitteratur.

UNICEF (2002). Implementation handbook for the convention on the rights of the child. Geneva: United Nations Publications.

Waterston, T., \& Mok, J. Y. Q. (2008). Violence against children: The UN report. Archives of Disease in Childhood, 93, 85-88. doi:10.1136/adc.2006.113340

Weinehall, K. (1997). Att växa upp i våldets närhet [Growing up in the proximity of violence]. Dissertation, Umeå Universitet, Pedagogiska Institutionen.

WHO (2002). World Report on Violence and Health. Geneva: World Health Organization. 